\title{
A Comparative Analysis of Interpretive Strategies in Contemporary Art Theory \\ and Its Implications to Discipline-Based Art Education \\ Rosalie Politsky
}

\section{Metacriticism in Art Education}

Art criticism has received quite a bit of attention from researchers in art education during the past fifteen years as a major component in educational reform (Barkan, 1966, Broudy, 1972, Feldman, 1970, Ecker, 1973, Smith, 1973). Moreover, since Barkan, such writers as Clark and Zimmerman (1978, 1981), Greer (1984), Lanier $(1982,1983)$ and DiBlasio (1985), have prescribed curriculum reform in relation to aesthetics as well (Russell, 1986). Concurrent with this increased interest in critical discourse and aesthetics, there has also developed a mode of curriculum theorizing that is termed educational metacriticism (Geahigan, 1979), which is a form of inquiry that attempts to explain what criticism and aesthetics is and how each should function in various educational settings (p. 3)

Despite, however, the growth in educational metacriticism, Geahigan (1979) asserts that there is a surprising lack of reference to other metacritical theories and a lack of debate about the adequacy of other theories which are offered as models for curriculum development.

There would be no problem, of course, if educational theorists agreed on the definitions and models prescribed for the teaching and 
learning of art criticism and aesthetics. However, academic writers such as Geahigan (1979, 1983), Russell (1986) and Hamblen (1986) have noted some fundamental problems in terms of theory adequacy.

The literature in art criticism provides a list of key concepts that Geahigan $(1979,1983)$ has found to vary in meaning. Interpretation is among them and, he asserts, is very much a matter of philosophical debate. In discussing the characteristics of the DBAE program, Clark, Day and Greer (1987) also identify interpretation as a concept that requires critical reflection. What significance does this ambiguity have for curriculum development? Hamblen (1986) suggests that the lack of extensive work in curriculum design has been due to the problem with structuring content that is elusive, contested and resistant to definitional consensus (p. 73). Thus, it appears that the act of interpretation has emerged as a contested concept in need of analysis and clarification.

What significance have art educators attributed to the concept and activity of interpretation? According to Smith (1973), the proper concern of interpretation is to find something about the meaning of the work of art. Smith asserts that interpretation is often taken as the most meaningful phase of the interaction between the viewer and the work of art. Furthermore, according to Clark, Day and Greer (1987), "Works of art present a complex of profound meanings in...visual metaphors. To comprehend meanings embodied in works of art requires education that develops students' abilities to unravel such meanings (p. 142).

Working Papers in Art Education 1988 
Parsons (1987) suggests that the ability to unravel meanings is associated not only with one's cognitive development, but also with the assumption that art is capable of layers of interpretation and that one grows in the ability to interpret the expressiveness of works of art. Lankford's (1984) research suggests that "no funded interpretation of a work of art ever exhausts the possibilities of meaning inherent in the work. A single work of art may speak with fresh significance to different people at different times under different circumstances" (p. 154).

From this very brief examination, it appears that although researchers in art education refer to interpretation as a key concept and one of the most desirable and enriching experiences in dealing with works of art, the concept is associated with vague and ambiguous concepts and activities such as 'aesthetic response,' 'meaning, ' 'significance,' 'profundity,' 'verification,' and 'subjective and public experience.'

\section{Contemporary Art Theory}

If one is puzzled to find that contemporary theory in art education offers a complex and perplexing picture of what interpretation is, then one may be dismayed to find even greater confusion and debate within contemporary art theory. Culler (1982), Eagleton (1983), and Margolis (1987) have all made this point very clear. In investigating the development of modern critical thought, Culler asserts that, "To write about critical theory at the beginning of the 1980's is...to intervene in a lively and confusing debate" (p. 7). In discussing contemporary interpretive strategies, Culler insists that one must confront the confusing and 
confused notion of post-structuralism and more specifically, the relation of deconstruction to other critical movements such as structuralism, phenomenology, feminist criticism, and psychoanalytic theory. Eagleton (1983) also notes the striking proliferation of literary theory over the last two decades. In his view, it is this proliferation that presents a major problem of accessibility. "But not much of this theoretical revolution has yet spread beyond a circle of specialists and enthusiasts: it has still to make its full impact on the student of Literature and the general reader" (vii). His list of interpretive strategies includes phenomenology, hermeneutics, reception theory, structuralism, semiotics, poststructuralism, psychoanalysis and political criticism. Margolis confirms the notion that we are undergoing radical changes in conceptual orientation, not only in regards to the arts but to the very nature of human culture. Margolis points to the accelerating pace with which these major changes are now succeeding one another. These themes, he asserts, can be recognized by anyone familiar with recent Western philosophy--both Anglo-American and Continental--in terms of pragmatism, deconstruction, Marxism, hermeneutics and late phenomenology (xi). The challenge, he continues, is to read through the developments of recent philosophy of art in order to determine the extent that there is any congruity. Implications for Art Education

The proliferation of critical theory is a response to understanding the complexity and diversity of post-structuralism in literature and postmodernism in art. It is also a response that manifests itself in the 
disillusionment in the art object and the scientific pretense of objectivity (Levin, 1985). Marantz (1988) is among the scholars in the field of art education who is attuned to this important development. "...in the beginning was the [Art] Object. Such a dogmatic declaration immediately separates the artifact from its maker and user, from its social origins" ( $p$. 259). And in this case, the user is one who engages in the process of interpretation. In terms of this investigation, then, two important questions come to light. First, how do these movements construe the task of interpretation? Secondly, how is the proliferation of critical theory effecting art education in general, and Discipline-based Art Education (DBAE) in particular?

\section{Purpose of the Study}

The primary purpose of this study is to: 1) survey the range of contemporary interpretive strategies; 2) analyze their ideological assumptions; 3) analyze Discipline-based Art Education in terms of its ideological assumptions; 4) determine what interpretive strategies

Discipline-based Art Education advocates; and 5) speculate as to Discipline-based Art Education's ability to effectively deal with contemporary art and post-modern interpretive strategies.

\section{Need for Ideological Analysis of Interpretive Strategies}

We have already identified the various interpretive strategies manifested in contemporary philosophy of art and art criticism. The question remains, how are these methods to be dealt with? Eagleton asserts that these methods have nothing whatsoever in common. He 
asserts that, "these forms of criticism differ from others because they define the object of analysis differently, have different values, beliefs and goals, and thus offer different kinds of strategy for the realizing of these goals" (1983, p. 212).

Mitchell (1983) vividly acknowledges the conflict rather than the consensus involving the arguments about the ideological and ethical implications of various interpretive strategies. He states that there is a revived need to historicize--that is, to scrutinize interpretive disciplines and their values.

\section{Significance of the Study}

When we combine the vagueness and ambiguity that surrounds the notion of interpretation as utilized in the field of art education, with the debate and confusion of recent interpretive movements, the problem greatly expands in scope resulting in an extremely fertile yet complex field of investigation.

However, even when we are dealing with an admitted confusion surrounding the proliferation of interpretive strategies, it is important to acknowledge along with Feldman (1988) the opportunity and responsibility of further research in this realm. He asserts that "...teachers of literature are several light years ahead of us [art educators]. That is, the theoretical materials we find new and innovative in art criticism have long been known to literary critics" (p. 61). How then, do we seize this opportunity and make the investigation into interpretive strategies relevant to the field of art education? 


\section{Discipline-based Art Education}

Because Discipline-based Art Education (DBAE) has emerged as a major approach to the teaching of art education, it has been selected as the focus for this investigation. DBAE is particularly important because of its appeal to the experts from the various disciplines as a means of achieving an assumed consensus in regards to curriculum problems. But as Efland (1987) has warned, it is a fallacy to assume that experts from the disciplines can be relied upon for consensus. This then, is the pivotal point of this investigation, namely, that there is no consensus in regards to the task of interpretation and that any appeal to the experts will result in competing views.

\section{Need for Ideological Analysis of Approaches to Art Education}

Several researchers have examined the notion of ideology and ideological analysis in recent years. DiBlasio (1976) cautions against ideological blindness, that is, the uncritical reflectiveness that impairs reflective awareness and prevents the identification of ideologies. Smith (1983) asserts that it is necessary to conduct a critical examination of ideologies within art education by asking what the ideology assumes about education, and what it assumes about art. Lanier (1980) advocates a cleaning out of our intellectual cupboards by ridding the profession of ideologies deemed as inadequate. Finally, Klempay-DiBlasio (1975) writes on the need for a critical examination of belief claims in art education curricula. 
Research Questions

This study will attempt to answer the following: 1) What is the range of interpretive strategies within contemporary art theory and what is the range of agreement and/or disagreement? 2) Can there be a systematic approach to the classification of the criteria for interpretation within contemporary art theory? 3) What metaphysical, ontological, epistemological, human nature views, value beliefs and methodological elements influence the criteria for interpretation within contemporary interpretive movements? 4) Given DBAE's ideological disposition, which interpretive strategies are coherent with its goals? 5) What interpretive strategies are being advocated by DBAE and are these strategies adequate to effectively assist art educators in implementing the diversity and complexity manifested in contemporary art?

\section{Assumptions of the Study}

The investigator perceived the study in terms of the following assumptions: 1) the discussion of literary criticism informs art criticism and is therefore, valuable to the discussion of art criticism;2) Knowledge of recent interpretive movements will lead to greater understanding of contemporary art and will enhance the theory and practice of art education in the realm of art criticism; 3 ) interpretive strategies may be conceived of as manifestations of a social order. Social theory provides paradigms that reflect the distinctive character of the social world, and therefore, may be a means of conducting a systematic analysis of contemporary interpretive 
strategies; 4) Discipline-based Art Education is a primary ideology in contemporary art education.

\section{Methodology}

This investigation will examine the literature on educational research and social theory in order to determine the scope and diversity of educational and sociological paradigms. Several models of social paradigms will be investigated and adapted for this investigation. They are the sociological paradigms of Burrell and Morgan (1985), and the methodological approaches of Mitroff and Kilmann (1978).

Morgan and Burrell's (1985) work is primarily in social and organizational theory in which they examine four mutually exclusive views of the social world and attempt to examine the assumptions that make them up. Their framework consists of: 1) The Functionalist Paradigm; 2) The Interpretive Paradigm; 3) The Radical Humanist Paradigm; and 4) The Radical Structuralist Paradigm. Each of the paradigms is analyzed in terms of its ontology, epistemology, human nature and methodology. These categories are further subdivided into a subjective-objective dimension.

Mitroff and Kilmann (1978) propose four distinct methodological approaches to the social sciences. Their four typologies are: a) The Analytic Scientist; b) The Conceptual Theorist; and d) The Particular Humanist. Each of these typologies are analyzed and compared with seven features taken from the literature in the philosophy, psychology and sociology of science. 


\section{Conclusion and Implications for the Study of Interpretation}

It has been hypothesized that the concept of interpretation and activities that constitute interpretive strategies will be dependent upon and will reflect the major assumptions of their particular ideology and sociological paradigms. Therefore, what constitutes the act of interpretation will vary considerably depending upon where the concept is located within the paradigms.

This methodology will be designed to examine the claim that the experts do not agree, that there is no consensus among the experts and that, indeed, they represent quite contradictory aims, goals, purposes, beliefs and methodologies. If this hypothesis is verified, then there are important implications for Discipline-based Art Education which has based its assumptions upon the notion of consensus and regulation.

However, there is a more positive purpose to this investigation. This researcher shares the same goals as articulated by Mitchell (1983), namely--the articulation of a positive sense of the politics of interpretation. As Mitchell asserts, there is considerably more to the politics of interpretation than the negative moment of unveiling concealed ideology.

Ideology need not be just a shameful secret. It can be the body of values affirmed by a community. The politics of interpretation need not be just a name for bias, prejudice, and unprincipled manipulation; it can also be an agenda for progressive action, a conception of interpretation as the liberation of suppressed or forgotten meanings, or as the envisioning of new meanings which may give direction to social change. (pp. 4-5) 


\section{References}

Barkan. M. (1966). Curriculum problems in art education. A Seminar in Art Education for Research and Curriculum Development. Cooperative Research Project No. V-002. University Park, Pennsylvania: The Pennsylvania State University, 240-253.

Broudy, H. (1972). Enlightened cherishing. Urbana, Illinois: University of Illinois Press.

Burell, G. \& Morgan, G. (1985). Sociological paradigms. An Organizational Analysis. Portsmith: $\mathrm{NH}$; Hinemann.

Clark, A., \& Zimmerman, E. (1978). A walk in the right direction: A model for visual arts education. Studies in Art Education, 19 (2), 34-47.

Clark, A. \& Zimmerman, E. (1981) Toward a discipline of art education. Phi Delta Kappa, 63 (1), 53-55.

Culler, J. (1986). On deconstruction. New York: Cornell University Press.

DiBlasio, R. (1977). A critical apparatus for the assessment of humanistic education: An analysis of ideology applied to the humanistic education movement in public schooling. Doctoral Dissertation. The Ohio State University. 320 pp.

Eagleton, T. (1983). Literary theory. Minneapolis: University of Minnesota Press.

Ecker, D. (1973). Analyzing children's talk about art. Journal of Aesthetic Education. VII (January) 58-73.

Feldman, E. (1970). Becoming human through art. Englewood Cliffs: Prentice Hall.

Feldman, E. (1988). The teacher as critic. In Research readings for discipline-based art education: A journey beyond creating (pp. 58-66). The National Art Education Association. (original work published 1973).

Geahigan, G. (1979). An analytic study of art criticism in curriculum contexts. Doctoral Dissertation. The Ohio State University. 616 pp.

Geahigan, G. (1983). Art criticism: An analysis of the concept. Issues in Art Education, 9 (1), 10-22.

Greer, W. D. (1984). Discipline-based art education: Approaching art as a 
Greer, W. D. (1984). Discipline-based art education: Approaching art as a subject of study. Studies in Art Education, 25 (4), 212-218.

Hamblen, K. (1986), Exploring contested concepts for aesthetic literacy. Journal of Aesthetic Education, 20 (2), 67-76.

Klempay-DiBlasio, M. (1985). Continuing the translation: further delineation of the DBAE format. Studies in Art Education, 26 (4), 197-205.

Lanier, V. (1982). The arts we see: A simplified introduction to the visual arts. New York: Teachers College Press.

Lanier, V. (1983). Beyond aesthetic education. Art Education, 36 (6), 31-37.

Lankford, L. (1984). A phenomenological methodology for art criticism. Studies in Art Education, 25 (3), 151-158.

Levin, K. (1985). Farewell to modernism. In R. Hertz (Ed.). Series of contemporary art. pp. 1-9. NJ: Prentice Hall.

Marantz, K. (1988), The object in our art education landscape, esthetically speaking. Studies in Art Education, 29 (3), 259-261.

Margolis, J. (Ed.). (1987). Philosophy looks at the arts. (3rd ed.).

Philadelphia: Temple University Press.

Mitchell, W. J. T. (Ed.). (1983). Politics of interpretation. Chicago: University of Chicago.

Mitroff, I. I. \& Kilmann, R. H. (1978). Methodological approaches to social science. In Washington: Jossey-Bass.

Parsons, M. J. (1987). Talk about a painting: A cognitive development analysis. Journal of Aesthetic Education, 24 (1), 37-55.

Russell, R. (1986), The aesthetician as a model in learning about art.

Studies in Art Education, 27 (4), 186-197.

Smith, R. A. (1973). Teaching aesthetic criticism in the schools. Journal of Aesthetic Education, 7 (January), 38-49. 